\title{
As an instance of Mersin province on child rearing according to socioeconomic level
}

\author{
Musa Eroğlu' ${ }^{1}$, Turhan Toros ${ }^{2}$ \\ Mehmet Miman ${ }^{3}$, Mehmet Cüneyt Birkök ${ }^{4}$
}

\begin{abstract}
The aim of this study is to search the parents who have children aged between 3 to 6 years in Mersin's Toros district, and to specify how their attitudes of child care- education. At the same time this study also searches the effects of parents' socioeconomic level of child rearing.

This study has been implemented on the 232 volunteer parents who have children aged between 3 and 6 years in Mersin's Toros district. Applied family life and child care -education scale which has been developed with Öner and Torun (1989), consisted of questionnaires which will affect the attitudes of the parents in terms of child care- education and this includes demographic information which will introduce the parents. These surveys have been performed by the parents who have children in Toros district's Playschools, kindergartens and day care center by one-to-one interviews. The data which is obtained from surveys by the help of the SPSS 16.0 packet program has been evaluated by using the rate per cents, arithmetic mean, standard deviation, $t$ - test of analysis of variance and one way ANOVA.

In consequence of this assessment has been seen the significant differences between participants' ages and protectiveness dimension $\mathrm{F}(3,228)=2,553 ; \mathrm{p}<0,050]$, and has been seen the meaningful differences between levels of income and overprotective dimension $[f(4,227)=3$, $361 ; \mathrm{p}<0,050]$

As a consequence has been seen the significance of the family's socioeconomic level of child rearing. Child-rearing attitudes of families with low socio-economic level had significantly more protective attitude.
\end{abstract}

Key Words: Child rearing; Family; child; Parental attitude

\footnotetext{
${ }^{1}$ Toros University, Department of Psychology, musa.eroglu@,toros.edu.tr

2 Assoc. Prof. Dr., Toros University, Department of Psychology, turhantoros@yahoo.com

3 Assoc. Prof. Dr., Toros University, Department of Industrial Engineering, Statistical Expert, mehmet.miman@,toros.edu.tr

${ }^{4}$ Assist. Prof. Dr., Sakarya University, Faculty of Education, birkok@sakarya.edu.tr
} 
Eroğlu, M., Toros, T., Miman, M. \& Birkök, M. C. (2013). As an instance of Mersin province on child rearing according to socioeconomic level. International Journal of Human Sciences, 10(2), 326-337. doi: 10.14687/ijhs.v10i2.2667

\section{Introduction}

Environmental factors are one of the most important effects of personality formation. Family is the most important factor among them. What determines this and form the basic relationship between mother, father and the child are the methods of rising up the children. Interaction between the parents and the child forms both the child's behavior and also affects the child's future behavior. While the child's personality is forming; parents' attitude has a very important impact and especially the application of "reward and punishment" have a very efficient role (Yeşilyaprak, 1989). Beginning from the infancy; roles and responsibilities should be given according to the child's age, ability and gender -role. If you loaded the children with other responsibilities except these ones; their feeling of confidence couldn't be stiffen. This can lead to the growth of children as dependent and incompetent individuals. If the child doesn't trust his environment he can be a liar or a cheater and if a child fails to obtain friends he can be withdrawn, silent and asocial (Yavuzer, 2011).

Being loved by the parents, balanced care and nutrition reinforces a sense of basic trust. If the children have intimacy with their parents then they would behave in a warm way to others. In short, it is crucial for how the child is treated by the family because the child would reflect the same to the outside (Kulaksızoğlu, 2011).

Family influence on human life begins before birth and remains in effect until the end of life. Family is a social institution and besides being physiological, its social, cultural and economic aspects format and also direct one's spiritual development, personality development and behaviors. (Yavuzer, 1996). Family's having such an effect on shaping the human life by means of the mother and the father who forms the essence of the family have great impact on raising children with healthy attitudes and personality. Because of the positive child-rearing attitudes contribute to the future of the child itself; thus providing a useful individual to the society (Yavuzer, 1999).

Some researches were conducted on children in their infancy and these researches show that especially the parents raising children 3 or 4 years old are notable for that the first years of life determines the shaping of the child's self-confidence which will lead to a determination of selfreliance in further years of the child's life. While children grow older, especially researches on the second childhood phase and adolescent phase show that it is very difficult to reach a definitive judgment on this issue (Mackey ve Fanning, 1998). Communication and interaction with the parents and their children determines the position of the child within the family. Family is the most effective socialization institution especially in the life of children during pre-school years. 
Eroğlu, M., Toros, T., Miman, M. \& Birkök, M. C. (2013). As an instance of Mersin province on child rearing according to socioeconomic level. International Journal of Human Sciences, 10(2), 326-337. doi: 10.14687/ijhs.v10i2.2667

Generation of the family, the physiological needs of the children, education and socialization of the child are the most important tasks among the functions of the family. In addition to these, protectiveness, sense of trust and developing a child compatible with the society are important, too. Thereby, family plays a significant role in the physical and psychological development of the child. (Demiriz, 2007) The children who will be the assurance of the future and are the youngest members of the society are the ones who have grown up in healthy families with good relationships. The attitudes of parents who are responsible for the childcare may be affected by the child's and their own personal characteristics and demographic qualities. In order for the children being perfect; the parents should not be oppressive. They should be flexible and tolerant. Oppressive, excessively tolerant, indifferent parents cause children to develop uncontrolled behavior. While parents are educating their children, they should be aware of their children's developmental characteristics and they should be able to meet their needs. (Yörükoğlu, 1995; Yavuzer; 2001; Nelsen; Lott and Glenn; 2002).

The level of income which arranges and controls the environment of the family essentially affects the development of the child directly or indirectly. The economic events that take place in the region where the family lives can also affect the development of the child. Attitudes within the family, especially between father and mother, have a key role in the development of the child. Ways of raising a child differs not only from culture to culture; but also from family to family. Every single socioeconomic group raises their child in accordance with their own culture, lifestyle and value system. Every parent has their own way of reward and punishment types for their children (Kulaksızoğlu, 2003). Besides, it is known that the children who have grown up in a safe and democratic family can develop their personalities, but the children who have grown up in strict and uncompanionably families cannot develop their personalities (Yıldırım, 2006).

Researches show that the children of the families with low level of income may have some cognitive, social, emotional and physical problems, which affects their successes at school. However, some researches also show that the education of parents about child education and development can remove these negative conditions (Kartal, 2007).

The best environment for the children is the family where the father and the mother are under the same roof, because they are the people whom the child communicates and interacts at first. Their being in a good relationship is crucial for the child. The attitudes of parents towards children may be affected from the child's qualities as well as their own personal and demographic qualities. The communication triangle between father-mother and child have short term or long term, positive or 
Eroğlu, M., Toros, T., Miman, M. \& Birkök, M. C. (2013). As an instance of Mersin province on child rearing according to socioeconomic level. International Journal of Human Sciences, 10(2), 326-337. doi: 10.14687/ijhs.v10i2.2667

negative effects on individuals; thus parents and children learn to behave properly or improperly towards the other (Güngör, 1995). While parents are raising their children, they should know their developmental characteristics in that period and they should be able to meet their needs. (Yörükoğlu, 1995; Yavuzer, 2001; Nelsen, Lott and Glenn, 2002).

The problems within the family may affect both the children and the parents physically and psychologically. Despite this fact, most of the parents are unwilling to get professional help to overcome these problems. It is really important that the problems either between the father and the mother or between the parents and the children should be solved before turning into serious conflicts(Yildırım, 2006).

In this study, it is aimed to define the attidues of parents who live in Mersin Toroslar and who have children between the ages 3 and 6. It is hoped that the results of this study will help parents to minimize their negative effects on children, and also to contribute to the effort of rearing healthy and qualified children by guiding parentage education studies.

\section{Method}

\section{Participants}

The samples are 232 fathers and mothers whose children attend to kindergartens and nursery schools. $64 \%$ of the participants were women, $36 \%$ were male. $95 \%$ of respondents were married, divorced, $2 \%$, and $3 \%$ widowed. $32 \%$ of respondents in primary schools, $20 \%$ of the secondary school, high school and $23.7 \%$ have $23 \%$ of the university, while $4 \%$ have received post-graduate education. Looking at the income level of $57 \%$ of the participants are low-income. rate of $27 \%$ in the middle income families $6,1,3 \%$ of the kind of high-income families.

Toroslar is a place where parents of different socioeconomic status live and where we can see lots of shanty houses. A written approval has been taken from those who took part in this study. random selection method was applied to reflect the reality of the results.

\section{Data Collection Tools}

In order to collect the data, a questionnaire consisted by two parts were used. In the first part, demographic qualities of the parents were studied and in the second part parental attitude research instrument (PARI) which was developed by Schaefer and Bell was used. (Öner, 1997) The answers of the parents were evaluated in five different dimensions. These dimensions were; 
Eroğlu, M., Toros, T., Miman, M. \& Birkök, M. C. (2013). As an instance of Mersin province on child rearing according to socioeconomic level. International Journal of Human Sciences, 10(2), 326-337. doi: 10.14687/ijhs.v10i2.2667

overprotectiveness, democratic attitude, the denial of his/her role, incompatibility between parents, pressure and discipline.

1. Dimension: Overprotectiveness: Parents are overprotectiveness. They interfere in their children's lives excessively and want them to be active, hardworking, also be dependent to their family. The items of this dimension are: 1, 3, 4, 7, 11, 12, 14, 26, 27, 28, 32, 34, 36, 46, $51,57$.

2. Dimension: Democratic Attitude and equality: Parents encourage their children to express their opinions freely. They treat their children like friends and they share lots of things with their children. The items of this dimension are: 13, 18, 22, 29, 37, 44, 45, 59 .

3. Dimension: The denial housewife: This dimension includes such topics as the supporting the dependence of the mother on her own mother or others, her dislike of being with children for a long time, nervousness, being scared of taking care of the newborn baby. The items of this dimension are: 6, 9, 16,17, 21, 23, 31, 38, 41, 42, 49, 52, 55.

4. Dimension: incompatibility of parents: The role of incompatibility between parents; thoughtlessness of the father and not helping enough to the mother in a child's development is included in this dimension. The items: 8, 19, 33, 40, 48 and 54.

5. Dimension: Pressure and discipline: The indications that emphasize negative child upbringing manners include pressures on aggressive and sexual behavior, believing in the strict discipline, forcing the child to accept the parents as the absolute domination. The terms are: $5,10,15,20,24,25,30,35,39,43,47,50,53,56,58,60$.

The implementation and evaluation of PARI: PARI ( Parental Attitute Research Instrument) questionnaire forms filled by parents who have children aged between 3 and 6 were planned in the following: 1 point was given in response to "don't agree at all", 2 points were given in response to "I hardly agree", 3 points were given in answer to "I agree" and 4 points were given in response to "I strongly agree". However, the responses given for the second, twenty-ninth and forty-fourth article was scored conversely. In other words, 1- point answers got 4 points. 2- point answers got 3 points. 3 - point answers got 2 points and 4 - point answers got 1 point in return.

The total score was obtained separately for each dimension. (Kulaksızoğlu, 1985) 
Eroğlu, M., Toros, T., Miman, M. \& Birkök, M. C. (2013). As an instance of Mersin province on child rearing according to socioeconomic level. International Journal of Human Sciences, 10(2), 326-337. doi: 10.14687/ijhs.v10i2.2667

\section{Results}

Table 1: Analysis of variance between participants ages, family life and attitude scale. (ANOVA)

\begin{tabular}{|c|c|c|c|c|c|c|}
\hline \multicolumn{2}{|l|}{ AGE } & $\begin{array}{l}\text { Sum of } \\
\text { Squares }\end{array}$ & df & $\begin{array}{l}\text { Mean } \\
\text { Square }\end{array}$ & $\mathrm{F}$ & Sig \\
\hline \multirow{3}{*}{$\begin{array}{l}\text { Overprotectiveness } \\
\text { aspect }\end{array}$} & Intergroup & 550,112 & 3 & 183,371 & \multirow[t]{3}{*}{2,553} & \multirow[t]{3}{*}{, 050} \\
\hline & Intragroup & 16377,612 & 228 & 71,832 & & \\
\hline & Total & 16927,724 & 231 & & & \\
\hline \multirow{3}{*}{\multicolumn{2}{|c|}{$\begin{array}{l}\text { Democratic behavior Intergroup } \\
\text { and equal treatment Intragroup } \\
\text { aspect } \\
\text { Total } \\
\end{array}$}} & 12,168 & 3 & 4,056 & \multirow[t]{3}{*}{313} & \multirow[t]{3}{*}{, 816} \\
\hline & & 2956,228 & 228 & 12,966 & & \\
\hline & & 2968,397 & 231 & & & \\
\hline \multirow{2}{*}{\multicolumn{2}{|c|}{$\begin{array}{l}\text { Objection to the Intergroup } \\
\text { housewifery aspect }\end{array}$}} & 99,923 & 3 & 33,308 & \multirow[t]{3}{*}{606} & \multirow[t]{3}{*}{, 612} \\
\hline & & 12535,969 & 228 & 54,982 & & \\
\hline & Total & 12635,892 & 231 & & & \\
\hline \multicolumn{2}{|c|}{ Spousal derangement Intergroup } & 86,058 & 3 & 28,686 & \multirow[t]{3}{*}{1,642} & \multirow[t]{3}{*}{, 180} \\
\hline aspect & Intragroup & 3982,730 & 228 & 17,468 & & \\
\hline & Total & 4068,789 & 231 & & & \\
\hline \multirow{3}{*}{$\begin{array}{l}\text { Pressure at } \\
\text { Discipline aspect }\end{array}$} & Intergroup & 612,829 & 3 & 204,276 & \multirow[t]{3}{*}{2,421} & \multirow[t]{3}{*}{, 067} \\
\hline & Intragroup & 19234,270 & 228 & 84,361 & & \\
\hline & Total & 19847,099 & 231 & & & \\
\hline
\end{tabular}

In table 1, according to variance analysis results (ANOVA), a remarkable difference is seen between the ages of the participants and overprotectiveness aspects. $F(3,228)=2,553 ; \mathrm{p}<0,050]$. According to variance analysis results (ANOVA), no significant difference was found between the participants' age and Democratic behavior or equal treatment aspects. $[\mathrm{F}(3,228)=0,313 ; \mathrm{p}>0,050]$. According to variance analysis results, (ANOVA) it is seen that there is a remarkable difference between participants' age and objection to housewifery aspects $[\mathrm{F}(3,228)=0,606 ; \mathrm{p}>0,050]$. According to variance analysis results, (ANOVA) no significant difference was found between the participants' age and spousal derangement. $[\mathrm{F}(3,228)=1,642 ; \mathrm{p}>0,050]$ According to variance analysis results, (ANOVA) no remarkable difference was found between participants age and pressure and discipline aspects. $[\mathrm{F}(3,228)=2,421 ; \mathrm{p}>0,050]$. 
Eroğlu, M., Toros, T., Miman, M. \& Birkök, M. C. (2013). As an instance of Mersin province on child rearing according to socioeconomic level. International Journal of Human Sciences, 10(2), 326-337. doi: 10.14687/ijhs.v10i2.2667

Table 2: Analysis of variance between participants' income states and family life attitude scale.

\begin{tabular}{|c|c|c|c|c|c|c|}
\hline \multicolumn{2}{|l|}{ Income State } & $\begin{array}{l}\text { Sum of } \\
\text { Squares }\end{array}$ & df & Mean Square & $\mathrm{F}$ & Sig. \\
\hline \multirow{3}{*}{$\begin{array}{l}\text { Overprotectiveness } \\
\text { aspect }\end{array}$} & Intergroup & 946,596 & 4 & \multirow{3}{*}{$\begin{array}{r}236,649 \\
70,401\end{array}$} & \multirow[t]{3}{*}{3,361} & \multirow[t]{3}{*}{, 011} \\
\hline & Intragroup & 15981,128 & 227 & & & \\
\hline & Total & 16927,724 & 231 & & & \\
\hline \multirow{3}{*}{\multicolumn{2}{|c|}{\begin{tabular}{|lc} 
Democratic & behavior Intergroup \\
and equal & treatment Intragroup \\
aspect & Total \\
& \\
\end{tabular}}} & 18,427 & 4 & \multirow{3}{*}{$\begin{array}{r}4,607 \\
12,995\end{array}$} & \multirow[t]{3}{*}{, 354} & \multirow[t]{3}{*}{, 841} \\
\hline & & 2949,970 & 227 & & & \\
\hline & & 2968,397 & 231 & & & \\
\hline \multirow{3}{*}{$\begin{array}{l}\text { Objection } \\
\text { housewifery aspect }\end{array}$} & Intergroup & 457,833 & 4 & \multirow{3}{*}{$\begin{array}{r}114,458 \\
53,648\end{array}$} & \multirow[t]{3}{*}{2,134} & \multirow[t]{3}{*}{, 078} \\
\hline & Intragroup & 12178,059 & 227 & & & \\
\hline & Total & 12635,892 & 231 & & & \\
\hline \multirow[t]{3}{*}{ Spousal derangement } & Intergroup & 280,220 & 4 & \multirow{3}{*}{$\begin{array}{l}70,055 \\
16,690\end{array}$} & \multirow[t]{3}{*}{4,197} & \multirow[t]{3}{*}{, 003} \\
\hline & Intragroup & 3788,569 & 227 & & & \\
\hline & To Total & 4068,789 & 231 & & & \\
\hline \multirow{3}{*}{$\begin{array}{l}\text { Pressure and Disciplin } \\
\text { aspect }\end{array}$} & Intergroup & 997,987 & 4 & \multirow{3}{*}{$\begin{array}{r}249,497 \\
83,036\end{array}$} & \multirow[t]{3}{*}{3,005} & \multirow[t]{3}{*}{, 019} \\
\hline & Intragroup & 18849,113 & 227 & & & \\
\hline & Total & 19847,099 & 231 & & & \\
\hline
\end{tabular}

In table 2, according to variance analysis results, (ANOVA) it is seen that there is a remarkable difference between participants' income states and overprotectiveness aspects $[\mathrm{F}(4,227)=3,361$; $\mathrm{p}<0,50]$. According to variance analysis results, (ANOVA) no significant difference was found between participants' income states and democratic behavior and equality aspects. [ $\mathrm{F}(4,227)=0,354 ; \mathrm{p}>0,050]$. According to variance analysis results, (ANOVA) no remarkable difference was found between participants' income state and objection to housewifery aspects. $[F(4,227)=2,134 ; \mathrm{p}>0,050]$. According to variance analysis results, (ANOVA) there is a remarkable difference between participants' income states and spousal derangement $[F(4,227)=4,197 ; \mathrm{p}<0.050]$. According to variance analysis results, (ANOVA) a remarkable difference was found between participants' income states and pressure and discipline aspects. $[\mathrm{F}(4,227)=3,005 ; \mathrm{p}<0,050]$. 
Eroğlu, M., Toros, T., Miman, M. \& Birkök, M. C. (2013). As an instance of Mersin province on child rearing according to socioeconomic level. International Journal of Human Sciences, 10(2), 326-337. doi: 10.14687/ijhs.v10i2.2667

Table 3: The difference analysis of participants' educational background and family life attitude scale.

\begin{tabular}{|c|c|c|c|c|c|c|}
\hline \multicolumn{2}{|l|}{$\begin{array}{l}\text { EDUCATIONAL } \\
\text { BACKGROUND }\end{array}$} & $\begin{array}{l}\text { Sum of } \\
\text { Squares }\end{array}$ & df & Mean Square & $\mathrm{F}$ & Sig. \\
\hline \multirow{3}{*}{$\begin{array}{l}\text { Overprotectiveness } \\
\text { aspect }\end{array}$} & Intergroup & 2901,802 & 4 & \multirow{3}{*}{$\begin{array}{r}725,451 \\
61,788\end{array}$} & \multirow[t]{3}{*}{11,741} & \multirow[t]{3}{*}{000} \\
\hline & Intragroup & 14025,922 & 227 & & & \\
\hline & Total & 16927,724 & 231 & & & \\
\hline \multirow{3}{*}{\multicolumn{2}{|c|}{$\begin{array}{l}\text { Democratic behavior Intergroup } \\
\text { and equality } \\
\text { enfranchisement aspect Intragroup } \\
\text { Total }\end{array}$}} & 100,142 & 4 & \multirow{3}{*}{$\begin{array}{l}25,035 \\
12,635\end{array}$} & \multirow[t]{3}{*}{1,981} & \multirow[t]{3}{*}{, 098} \\
\hline & & 2868,255 & 227 & & & \\
\hline & & 2968,397 & 231 & & & \\
\hline \multirow{3}{*}{$\begin{array}{l}\text { Objection } \\
\text { housewifery aspect }\end{array}$} & Intergroup & 1033,254 & 4 & \multirow{3}{*}{$\begin{array}{r}258,314 \\
51,113\end{array}$} & \multirow[t]{3}{*}{5,054} & \multirow[t]{3}{*}{, 001} \\
\hline & Intragroup & 11602,638 & 227 & & & \\
\hline & Total & 12635,892 & 231 & & & \\
\hline \multirow[t]{3}{*}{ Spousal derangement } & Intergroup & 602,696 & 4 & \multirow{3}{*}{$\begin{array}{r}150,674 \\
15,269\end{array}$} & \multirow[t]{3}{*}{9,868} & \multirow[t]{3}{*}{, 000} \\
\hline & Intragroup & 3466,092 & 227 & & & \\
\hline & Total & 4068,789 & 231 & & & \\
\hline \multirow{3}{*}{\multicolumn{2}{|c|}{$\begin{array}{l}\text { Pressure and Discipline Intergroup } \\
\text { aspect } \\
\qquad \begin{array}{l}\text { Intragroup } \\
\text { Total }\end{array}\end{array}$}} & 4648,850 & 4 & \multirow{3}{*}{$\begin{array}{r}1162,212 \\
66,953\end{array}$} & \multirow[t]{3}{*}{17,359} & \multirow[t]{3}{*}{, 000} \\
\hline & & 15198,249 & 227 & & & \\
\hline & & 19847,099 & 231 & & & \\
\hline
\end{tabular}

In table 3, according to variance analysis results, (ANOVA) a remarkable difference was found between participants' educational background and Overprotectiveness aspect $[\mathrm{F}(4,227)=11,741 ; \mathrm{p}<0,050]$. According to variance analysis results, (ANOVA) no remarkable difference was found between participants' educational background and democratic behavior and equality aspect. $\mathrm{F}(4,227)=1,981 ; \mathrm{p}>0,050]$. According to variance analysis results, (ANOVA) a remarkable difference was found between participants' educational background and objection to housewifery aspect. $[\mathrm{F}(4,227)=5,054 ; \mathrm{p}<0,050]$. According to variance analysis results, (ANOVA) a remarkable difference was found between participants' educational background and spousal derangement. $[\mathrm{F}(4,227)=9,868 ; \mathrm{p}<0,050]$ According to variance analysis results, (ANOVA) a remarkable difference was found between participants' educational background and pressure and discipline aspect $[\mathrm{F}(4,227)=17,359 ; \mathrm{p}<0,050]$. 
Eroğlu, M., Toros, T., Miman, M. \& Birkök, M. C. (2013). As an instance of Mersin province on child rearing according to socioeconomic level. International Journal of Human Sciences, 10(2), 326-337. doi: 10.14687/ijhs.v10i2.2667

Table 4: Analysis of variance between participants' gender and family life attitude scale ( $T$ test)

\begin{tabular}{|c|c|c|c|c|c|c|c|}
\hline \multirow[t]{2}{*}{ SEX } & \multirow[b]{2}{*}{$\mathrm{t}$} & \multirow[b]{2}{*}{$\mathrm{df}$} & \multirow{2}{*}{$\begin{array}{l}\text { Sig. } \\
(2- \\
\text { tailed) }\end{array}$} & \multirow{2}{*}{$\begin{array}{c}\text { Mean } \\
\text { Difference }\end{array}$} & \multirow{2}{*}{$\begin{array}{l}\text { Std. Error } \\
\text { Difference }\end{array}$} & \multicolumn{2}{|c|}{$\begin{array}{c}95 \% \text { Confidence Interval } \\
\text { of the Difference }\end{array}$} \\
\hline & & & & & & Lower & Upper \\
\hline Overprotectiveness aspect &, 066 & 230 & ,947 & ,07763 & 1,17501 & $-2,23754$ & 2,39279 \\
\hline $\begin{array}{l}\text { Democratic behavior and } \\
\text { equal treatment aspect }\end{array}$ &,- 171 & 230 & ,865 &,- 08393 & ,49202 & $-1,05337$ & ,88551 \\
\hline $\begin{array}{l}\text { Refusing the housewifery } \\
\text { aspect }\end{array}$ &,- 401 & 230 & 689 &,- 40729 & 1,01484 & $-2,40687$ & 1,59228 \\
\hline Spousal derangement & $-1,995$ & 230 & 047 & $-1,13956$ & ,57116 & $-2,26493$ &,- 01420 \\
\hline $\begin{array}{l}\text { Pressure and Discipline } \\
\text { aspect }\end{array}$ & 262 & 230 & ,794 & ,33323 & 1,27213 & $-2,17329$ & 2,83974 \\
\hline
\end{tabular}

According to T- test analysis, in the answers which were given in family life attitude scale, the difference between males' and females' answers which were given for spousal subsistence is found meaningful $(p<0,05)$.

\section{Discussions and Conclusions}

This current study was done to examine the attitudes of parents about child-rearing who came from different socioeconomic status and who had children between the ages of 3-6. At the end of this study, conclusions below were reached. According to the results of analysis of variance, it was found that there was a significant difference between the participants' age and the level of overprotection. It was thought that parents, who had children at their late ages, become more protective. There were no significant differences between the age level of participants and their democratic stance and their equality level. It was thought that age factor did not have a big influence on parents' attitude about their democratic stance on their family. It observed that there were not any meaningful differences between the ages of the participants and their rejection of housewifery. It was thought that the level of refusal housewifery was affected by other factors which were unrelated to the age factor. There was no significant difference between the age of the participants and wife-husband disagreements. It was not found a significant difference between the age level of the participants and their level of pressure and discipline. It was found that there is a meaningful difference between the income levels of the participants and the level of overprotection. It was considered that changes in the income levels of parents would affect the level of child protection. There were not found any significant differences between the income 
Eroğlu, M., Toros, T., Miman, M. \& Birkök, M. C. (2013). As an instance of Mersin province on child rearing according to socioeconomic level. International Journal of Human Sciences, 10(2), 326-337. doi: 10.14687/ijhs.v10i2.2667

levels of the participants and their levels of pressure and discipline. It was not found; there were not any meaningful differences in the income levels of the participants and their rejection of housewifery. There was an important difference between the ranges of income levels of the participants and their rejection on housewifery. It was found that there was a significant difference between income levels of the participants and their level of pressure and discipline. According to the results of the analysis of variance, there was an important difference between the educational status of the participants and their level of overprotection. It was not reached that there was a meaningful difference between the educational status of the participants and their level of pressure and discipline. There was an important difference between the educational status of the participants and their rejection of housewifery. Results revealed that there was a significant difference between the educational status of the participants and wife-husband disagreements. It was reached that there was a meaningful difference in the educational status of the participants and their level of pressure and discipline.

From the birth, and even from the time which baby settle down to the mother's womb, all children need to be cared and they are dependent on the protection of their parents for a long time. Also, the children need help with their physical and mental development, on being aware of $\mathrm{s} /$ he was an individual and need help for their development of personality as well as their need for socialization. Parents play a vital role in the child's development. In this context, no matter what type of family a child has, when a new member joins in a family, this baby brings new responsibilities to his/her family in order to satisfy newborn's socialization. (Semerci, 2012).

Parents should arrange a democratic environment for their family. In that environment, children could say their ideas and wishes easily. At the same time, children's positive behaviors should be rewarded. If the children make any mistake, parents should show the child that the behavior s/he performed is wrong and they should teach the child how s/he should behave instead.

If we want to bring up our children both mentally and socially competent individuals, parental supervision is needed. It should be remembered that the purpose of socialization is not being governed passively by external elements; its purpose is providing self-management. While raising a child, behaving overly restrictive or excessively freely has an influence on social development (Yavuzer, 2011).

Parents should have information about children's developmental stages and they also have to know the causes of children's behaviors in the stages that they belonged. In this way, parents will be 
Eroğlu, M., Toros, T., Miman, M. \& Birkök, M. C. (2013). As an instance of Mersin province on child rearing according to socioeconomic level. International Journal of Human Sciences, 10(2), 326-337. doi: 10.14687/ijhs.v10i2.2667

sensitive about children's physically and mentally needs. Parents should be aware of the negative effects of the classical authoritarian attitudes. For raising children on the democratic family environment, firstly parents' positive attitudes should be valued.

If the issues which are related to children and family will take part of training curriculum in all the educational stages, this will help parents get ready for their parental roles.

Parents should be consistent with their behaviors and discourses and they have to be aware that they are a model for their children. In order to satisfy children's personality development in a positive manner, children's independent behaviors should be supported. Most importantly, while bringing up the children, the family bond with love between the child and parents is crucial and the parents should make the child feel that s/he is important.

In conclusion, it has been seen that for rearing a child, the socio-economical status of the family was a very noteworthy factor.

\section{Bibliography}

Demiriz S. (1997). 9 ve 12 Yaş çocuklarının enlik kavramı ile anne-baba tutumları arasındaki ilişkinin incelenmesi. Yayınlanmamış doktora tezi. Gazi Üniversitesi Sosyal Bilimler Enstitüsü, Ankara.

Giagazoğlu, P., Cyprus, A., Fotiadou E., Angelopoulou, N. ( 2007), The effect of residential area and mothers' education on motor development of preschool aged children in Greece. Early child development and care.

Gage, J. R. Don. "Patterns of Achievement and Self-Concept Among Students in a Three-Ethnic Community". Educational Research Association, October, 1984.

Güngör, A (1995). Aile içi etkileşim, Ankara: Gazi Üniversitesi Mesleki Eğitim Fakültesi

Kasatura, İ. (1998). Kişilik ve Özgüven. Evrim Yayınevi, İstanbul.

Kulaksızoğlu, A., (2003) kişisel gelişim uygulamaları, Nobel yayıncılık, Ankara.

Kulaksızoğlu, A. (1985). ergen-aile çatışmaları ile annelerin tutumları arasındaki ilişki ve eren problemleri. Yayınlanmamış doktora tezi

Kulaksızoğlu,A. (2011). Ergenin Temel Gelişim Özellikleri, Timaş Yayınları (2. Baskı)

Myers, R. (1996). Hayatta kalan on iki, Erken Çocukluk Eğitimi Programlarının Güçlendirilmesi (Çev: R. Ağış Bakay, E.Ünlü). İstanbul: AÇEV, yayın no:5.

McKay M. Ve Fanning P.(1998) Özgüven Yaratılması ve Korunması. Çeviren: Anita Tatlier, Epsilon Yayınevi, İstanbul.

Öner, N. (1996). 'Türkiye’ de kullanılan psikolojik testler, bir başvuru kaynağı. İstanbul: Boğaziçi Üniversitesi Yayınları.

Semerci, M. (2012) Çocuğun Kişilik Gelişiminde Ailenin RolüUluslararası Katılımlı Çocuk İhityaçları Sempozyumu, . Ankara.

Torun, A. (1989) A preliminary form of scale on mother's attitudes toward highly competitive school entrance exams for fifth grade students, Master of Arts in educational sciences. İstanbul: Boğaziçi university.

Yavuzer, H.,(2011) Anne Baba Tutumları, Timaş yayınları (2. Baskı). ss 13 

to socioeconomic level. International Journal of Human Sciences, 10(2), 326-337. doi: 10.14687/ijhs.v10i2.2667

Yavuzer, H., (1996) Çocuk ve Suç, Remzi Yayınevi(4.Baskı). İstanbul ss. 134

Yavuzer, H. (1999). Ana - Baba ve Çocuk,12. Basım, İstanbul, Remzi kitabevi, 179-184

Yavuzer, H. (2001). Yaygin Ana- Baba tutumlan1, Ana Baba Okulu, (15. Basım) Remzi kitabevi, Ankara.

Yeşilyaprak, B., (1989) ”Anne-Baba Tutumlarının Kişilik Gelişimi Üzerine Etkisine İlişkin Bir Araştırma". Ya-Pa 6. Okul Öncesi Eğitimi ve Yaygınlaştırılması Semineri, İstanbul.

Yıldırım, İ (2006) Anne Baba Desteği ve Başarı, Anı Yayıncılık, Ankara . 1. Kastamonu Eğitim Dergisi.

Yörükoğlu, A. (1995). Çocuk Ruh Sağlı̆̆ı, Esin Yayınevi, İstanbul. 